\title{
Response of Apricot Trees to Ground Fertilization and Foliar Spraying
}

\author{
Raad Taha Mohammed Ali ${ }^{1}$, Akram Abdul-Kadhim Hadi ${ }^{2}$, Mawahib Midhat Hussein ${ }^{3}$ \\ \{Raadbalaket87@gmail.com,com.akr@atu.edu.iq, mawaheb.hussen@atu.edu.iq\}
}

AL-Furat Al-Awsat Technical University, $\operatorname{Iraq}^{1}{ }^{\prime}{ }^{\prime}{ }_{3}$

\begin{abstract}
The response of the apricot tree to combinations of fertilization with Qrop Complex and foliar spraying with seaweed extract (Alge-Zone) and their interactions in some chemical and yield traits are discussed. This includes the content of leaves Of chlorophyll and nutrients, Fruit weight (g), yield per tree $\mathrm{kg}$. tree -1 , percentage of total soluble solids (T.S.S). The randomized complete block design (R.C.B.D) was used with three replicates including the least significant difference (LSD) to compare the means at the 0.05 probability level. The results showed that the ground fertilizer with Qrop Complex gave an increase in the studied characteristics, and the foliar spraying with seaweed extract (Alge-Zone) had a positive effect on each of the leaves' content of chlorophyll and nutrients (nitrogen, phosphorous, potassium, boron and iron). Fruit Weight (g), The yield of one tree $\mathrm{kg}$. tree -1 , the percentage of total soluble solids (T.S.S). As for the interaction treatment, the ground fertilization with Qrop Complex fertilizer (600 g.tree-1) and foliar spraying with seaweed extract (Alge-Zone) at a concentration of $3 \mathrm{ml}$. L-1 significantly excelled in giving the best results in the studied traits which the content of leaves Of chlorophyll (54.67 SPAD), content of leaves Of nutrients (nitrogen, phosphorous, potassium, boron, and iron) of $(1.60 \%, 0.47 \%, 1.59,50.30 \mathrm{mg} . \mathrm{kg}-1$ and $251.67 \mathrm{mg} . \mathrm{kg}-$ 1) respectively, Fruit weight of $(16.96 \mathrm{~g})$, yield per tree $(15.77 \mathrm{~kg}$. tree -1$)$ and percentage of total soluble solids (T.S.S) of (15.66).
\end{abstract}

Keywords: Apricot, Alge-Zone, Foliar Spraying, Ground Fertilization.

\section{Introduction}

Follow the apricot Prunus armeniaca L. of the Rosaceae family. It is a fruit of the temperate region and the Mediterranean basin, which needs a period of cooling during the autumn and winter seasons to end the dormancy phase in the trees [1]. It was believed that the original home of the apricot is Armenia, but recent studies have shown that it is likely that its origin country is West and Central Asia [2]. It extends eastward to China, and from these areas, it moved to Greece and some European countries, then moved from it to Syria and some North African countries, North America, and Australia [3]. The word Apricot dates to the Greeks, where it was called AL-Praecox, which means early fruit [4]. Apricot is one of the summer fruits of high nutritional value that enters beside fresh consumption in many food industries, the most important of which are juices, jams, and apricot chips, which increase its economic value [5]. Ground feeding with nutrients for crops is one of the most important foundations of agricultural production and plant life preservation and providing nutrients in a balanced manner positively affects the growth and development of plants [6]. The compound fertilizer KPN is one of the 
important nutrients to improve the type of fruits and increase production in fruit trees through ground addition or spraying on trees and within the concentrations recommended by the companies producing it is important. Apricots, such as nitrogen, phosphorous, and potassium, in addition to containing small mineral elements to grow well, increase their yield and improve the quality of their fruits [7]. Studies also indicated that the availability of potassium in appropriate quantities plays an important role in improving the quality and productivity of trees. The importance of potassium comes in that it enters many vital processes in plant cells and is based on regulating the osmotic pressure of cells [8]. It increases the plant's ability to retain water and contributes to the process of opening and closing plant stomata [9], as well as its role in stimulating and activating the work of plant enzymes and many other vital processes [10]. seaweed extract is one of the basic materials that can be added or sprayed to the plant and the soil to provide the plant with the basic elements because it contains the necessary macro and micronutrients, some hormones, and growth regulators such as auxins, gibberellins and cytokinin's [11], These compounds increase the growth of roots and vegetative system and increase the amount of The yield, improving its quality, and increasing the aging of the fruits Plant resistance to biotic and abiotic stress[12], Also these extracts increase Efficient nutrient absorption in apples and increases the content of chlorophyll in leaves and increases From the processes of photosynthesis and respiration, and these compounds May act as an antioxidant because it contains alpha-tocopherol and Beta-carotene, niacin, thymine and ascorbic acid Through its role in increasing the activity of enzymes glutathione reductase Superoxide ascorbate peroxidase and dismutase[13], The aim of this research is to know the role of Qrop Complex fertilizer and seaweed extract in improving the quality and quantity of fruits.

\section{Materials and Methods}

The experiment was conducted in 2018-2019 private orchards in the Awfi region / Babylon province to study the effect of fertilization with Qrop Complex as shown in Table 1 and foliar spraying with seaweed extract (Alge-Zone) table and their interactions on some chemical traits and the result such as the content of chlorophyll in leaves (SPAD) and (nitrogen, phosphorous, potassium, boron and iron), average fruit weight (g), yield per tree kg.tree-1, percentage of total soluble solids (TSS)at the age of 6 years and almost homogeneous in length and size and planted with dimensions of $4 * 3$ for this cultivar grafted on the seed origin. 48 trees were elected and all the required service operations for trees such as irrigation, fertilization, weeding, and control were conducted equally. In this experiment, two factors were used, the first being the ground fertilization with Qrop Complex fertilizer at four levels (control treatment, 200 g.L-1, 400 g.L1, 600 g.L-1). The second factor is foliar spraying with seaweed extract (Alge-Zone)) at four concentrations (the control treatment, $1 \mathrm{ml} . \mathrm{L}-1,2 \mathrm{ml} . \mathrm{L}-1,3 \mathrm{ml} . \mathrm{L}-1$ ) and accordingly it is a factorial experiment $4 * 4=16$ treatments. The Randomized Complete Block Design (RCBD) with three replicates and one tree for the experimental unit, seaweed extract sprays were conducted at two dates after flowering and after flowers set. At the 0.05 probability level, the findings were statistically analysed using the least significant difference (LSD) to compare the means [3].

Table 1. The contents of the fertilizer Qrop Complex.

\begin{tabular}{|l|l|l|l|l|l|}
\hline So3 & Mgo & $\mathbf{C a}^{++}$ & $\mathbf{K}^{+}$ & $\mathbf{P}$ & $\mathbf{N}$ \\
\hline
\end{tabular}




\begin{tabular}{|l|l|l|l|l|l|}
\hline 14 & 2 & 3 & 24 & 6 & 12 \\
\hline
\end{tabular}

\section{Studies Traits}

1- Chlorophyll content of leaves (SPAD): The chlorophyll concentration was estimated in leaves when they are on trees using the manual scale SPAD meter [14].

2- Content of leaves of nutrients (N, P, K, B, and Fe ):

Each seedling and replicate had leaf samples obtained, which were then rinsed with distilled water and placed in perforated paper bags. Then, for 48 hours and until confirmed, it was dried in an electric oven at 65 degrees Celsius. The samples were then pulverised, and $0.5 \mathrm{~g}$ of the powdered sample (dry leaves) was obtained. According to Black, 1965, the nitrogen concentration was calculated using the Microkjedhal apparatus and it was digested by concentrated $96 \%$ sulfuric acid (15) $\mathrm{ml}$ and ( $3 \mathrm{~g}$ ) of the mixture (copper sulfate 0$) .2+$ potassium sulfate 0.8 ) with heating for an hour, then transfer the digestion solution to a volumetric flask with a capacity of $50 \mathrm{~cm} 3$ and complete the volume with distilled water in the amount of (20) $\mathrm{ml}$ and then wiped using a standard hydrochloric acid 0.1 Then the nitrogen percentage was calculated according to the equation.

a- Nitrogen content of leaves (\%): it was estimated using the Microkjedhal device according to the method [15].

b- The phosphorous content of the leaves $(\%)$ : was also estimated by the method of soft digestion by using ammonium molybdate and ascorbic acid using a spectrophotometer Where (10) $\mathrm{ml}$ of the solution of the digested sample was taken and placed in a volumetric flask, then (0.1) $\mathrm{g}$ of ascorbic acid was added and (4) $\mathrm{ml}$ of ammonium molybdate solution for each sample, after which the contents of the beaker were heated on a hot plate for one minute, so the colour of the solution became blue, then read along the wavelength of $620 \mathrm{~nm}$. At the same time, the samples of standard prepared solutions were read at the same time and method of preparing the digested sample, then the ratio was calculated Percentage of phosphorous according [15], [16]. c- Potassium content of the leaves (\%): using a photometer flame as mentioned in [17]

d- Boron content of the leaves (mg.kg-1): it was determined by a Spectrophotometer Absorption Atomic device according to the method of [18 ], [19].

e- The iron content of the leaves (mg.kg-1): It was determined by a Spectrophotometer Absorption Atomic device according to the method of [18], [19]

7- Average weight of the fruit $(\mathrm{g})$ : according to the average weight of the fruit, weighing 10 fruits from each experimental unit, using a sensitive electric scale of the Metller type, then extracting the average weight of the fruit, estimated in grams.

8 - The yield of one tree $\mathrm{kg}$. tree -1: According to the yield of one tree by multiplying the average weight of one fruit by the number of fruits per tree, estimated in kilograms.

9- Percentage of total soluble solids (T.S.S): The percentage of total soluble solids in fruits was measured by taking a drop of fruit juice for each experimental unit using the Refractometer Hand device directly on the device.

\section{Results}

\subsection{Chlorophyll Content (SPAD)}


Table 2 shows that there are significant differences in the average chlorophyll content of leaves (SPAD) due to the effect of adding Qrop Complex fertiliser at an average of $600 \mathrm{~g}$. tree-1, which resulted in the highest average chlorophyll content of leaves (51.32 SPAD) compared to the control treatment, which resulted in the lowest average of chlorophyll content of leaves $(51.32$ SPAD) (35.45 SPAD). As for the foliar spraying treatment with seaweed extract, the concentration of $3 \mathrm{ml}$.L-1 was excelled on the rest of the concentration and gave the highest rate of (45.67 SPAD) compared to the control treatment, which gave the lowest average for that trait reached (40.27 SPAD), As for the interaction treatments, the treatment of Qrop Complex fertilizer at an average of 600 g.tree-1 Alge-Zone seaweed extract at a concentration of 3 ml.L1 was excelled and it gave the highest significant average in the chlorophyll content of leaves, which amounted to (54.67 SPAD) compared to the control that gave) 32.67 SPAD), which is the lowest average for this trait.

Table 2. Effect of ground fertilization and foliar spraying with seaweed extract on Leaf content of chlorophyll (SPAD) for apricot trees cultivar Zaini.

\begin{tabular}{|c|c|c|c|c|c|}
\hline \multirow{2}{*}{$\begin{array}{c}\text { Ground } \\
\text { Fertilization }\end{array}$} & \multicolumn{4}{|c|}{ Foliar Spraying with Seaweed Extract } & \multirow{2}{*}{ Average } \\
\hline & A0 & A1 & A2 & A3 & \\
\hline F0 & 32.63 & 35.01 & 36.33 & 37.81 & 35.45 \\
\hline F1 & 38.00 & 41.45 & 42.36 & 42.88 & 41.17 \\
\hline F2 & 42.97 & 44.41 & 45.34 & 47.30 & 45.01 \\
\hline F3 & 47.49 & 50.84 & 52.27 & 54.67 & 51.32 \\
\hline average & 40.27 & 42.93 & 44.08 & 45.67 & \\
\hline L.S.D0.05 & \multicolumn{2}{|c|}{$\mathrm{F}=4.920$} & \multicolumn{2}{|c|}{$\mathrm{A}=4.920$} & $\mathrm{~F}^{*} \mathrm{~A}=9.840$ \\
\hline
\end{tabular}

\subsection{Nitrogen Content of Leaves (\%)}

Table 3 indicated that the fertilization using Qrop Complex fertilizer at an average of $600 \mathrm{~g}$.tree1 had a significant effect on the average nitrogen content of the leaves of the apricot trees understudy, where these trees excelled and give the highest average for that trait amounted to $(1.53 \%)$. Compared to the control treatment that gave the lowest average $(1.19 \%)$. It is also noted from the same table that the trees differ among themselves in the nitrogen content of leaves. The trees sprayed with seaweed extract Alge-Zone at a concentration of $3 \mathrm{ml} . \mathrm{L}-1$ excelled on the rest of the concentrations and gave (1.42\%) compared to the control treatment that gave $(1.32 \%)$. In terms of the interaction between the Qrop Complex fertiliser and the seaweed extract Alge-Zone, the same table's data show that the interaction trees Qrop Complex fertiliser excelled at an average of $600 \mathrm{~g}$. Tree- 1 with a $3 \mathrm{ml}$ concentration of seaweed extract. When compared to the control therapy, which delivered the lowest average for the same attribute (1.60 percent), L-1 gave the highest average for the same trait (1.60 percent) (1.12 percent ).

Table 3. Effect of ground fertilization and foliar spraying with seaweed extract on leaves content of Nitrogen (\%) for apricot trees cultivar Zaini.

\begin{tabular}{|c|c|c|c|c|c|}
\hline Ground & \multicolumn{4}{|c|}{ Foliar Spraying with Seaweed Extract } & \multirow{2}{*}{ Average } \\
\cline { 2 - 5 } Fertilization & A0 & A1 & A2 & A3 & \\
\hline
\end{tabular}




\begin{tabular}{|c|c|c|c|c|c|}
\hline F0 & 1.12 & 1.18 & 1.22 & 1.27 & 1.19 \\
\hline F1 & 1.29 & 1.33 & 1.35 & 1.36 & 1.33 \\
\hline F2 & 1.39 & 1.41 & 1.43 & 1.46 & 1.42 \\
\hline F3 & 1.47 & 1.49 & 1.55 & 1.60 & 1.53 \\
\hline average & 1.32 & 1.35 & 1.39 & 1.42 & \\
\hline L.S.D0.05 & \multicolumn{2}{|c|}{$\mathrm{F}=0.161$} & $\mathrm{~A}=0.161$ & $\mathrm{~F} * \mathrm{~A}=0.323$ \\
\hline
\end{tabular}

\subsection{The Phosphorous Content of The Leaves (\%)}

The results in Table 4 indicate that there are significant differences between the average phosphorous content of leaves (\%) due to the fertilizer treatments. The trees were significantly excelled to the fertilizer treatment with Qrop Complex at an average of 600 g.tree- 1 on the rest of the treatments $(0.42 \%)$ When the control treatment gave the lowest average $(0.16 \%)$. It is also evident from the same table that the trees showed significant differences among themselves in the phosphorous content of leaves (\%) when sprayed with seaweed extract Alge-Zone. The trees sprayed with a concentration of $3 \mathrm{ml} . \mathrm{L}-1$ excelled in the leaves content of phosphorous $(\%)$ and gave $(0.33 \%)$ ) compared to the control treatment that gave the lowest average for this trait $(0.26 \%)$. The interaction of the Qrop Complex fertiliser treatment with Alge-Zone seaweed extract had a substantial impact on the leaves' phosphorous content ( percent ). The Qrop Complex fertiliser application at an average of $600 \mathrm{mg}$, according to the same table's results. Interaction of Tree-1 with Alge-Zone seaweed extract. The trees sprayed with a concentration of $3 \mathrm{ml} . \mathrm{L}-1$, which yielded the greatest rates of ( 0.47 percent), outperformed the control treatment, which yielded the lowest average of ( 0.35 percent) $(0.12$ percent $)$.

Table 4. Effect of ground fertilization and foliar spraying with seaweed extract on leaves content of phosphorous (\%) for apricot trees cultivar Zaini.

\begin{tabular}{|c|c|c|c|c|c|}
\hline \multirow{2}{*}{$\begin{array}{c}\text { Ground } \\
\text { Fertilization }\end{array}$} & \multicolumn{4}{|c|}{ Foliar Spraying with Seaweed Extract } & \multirow{2}{*}{ Average } \\
\cline { 2 - 5 } & A0 & A1 & A2 & A3 & \\
\hline F0 & 0.12 & 0.16 & 0.17 & 0.19 & 0.16 \\
\hline F1 & 0.22 & 0.25 & 0.27 & 0.28 & 0.26 \\
\hline F2 & 0.30 & 0.32 & 0.34 & 0.37 & 0.33 \\
\hline F3 & 0.38 & 0.40 & 0.44 & 0.47 & 0.42 \\
\hline average & 0.26 & 0.29 & 0.31 & 0.33 & \\
\hline L.S.D0.05 & \multicolumn{3}{|c|}{$\mathrm{F}=2.674$} & $\mathrm{~A}=2.674$ & $\mathrm{~F} * \mathrm{~A}=5.349$ \\
\hline
\end{tabular}

\subsection{Potassium content of leaves $(\%)$}

Table 5 demonstrates that when the potassium content of leaves was given 600 g.tree-1, ground fertilisation with Qrop Complex fertiliser had a substantial effect. This treatment had the highest average rate for this feature (1.54 percent), while the control treatment had the lowest average 
rate (1.24 percent) for apricot trees. When it came to spraying treatments, the trees treated with Alge-Zone seaweed extract, sprayed at a concentration of $3 \mathrm{ml} . \mathrm{L}-1$, performed exceptionally well. In comparison to the control treatment, which had the lowest average (1.54 percent), this had the greatest average (1.54 percent) (1.24 percent ). The interaction had a substantial influence on the potassium content of leaves, according to the same table, as it achieved the maximum average potassium content in leaves when treated with Qrop Complex fertiliser at an average of $600 \mathrm{~g}$. Alge-Zone, a seaweed extract, interacts with tree-1. Qrop Complex, at a concentration of $600 \mathrm{~g}$, was applied to the trees. Tree-1 interaction with spraying $3 \mathrm{ml} . \mathrm{L}-1$ seaweed extract produced the highest average of (1.44 percent) when compared to the control treatment, which produced the lowest average for that attribute (1.09 percent ).

Table 5. Effect of ground fertilization and foliar spraying with seaweed extract on Potassium content of leaves $(\%)$ for apricot trees cultivar Zaini.

\begin{tabular}{|c|c|c|c|c|c|}
\hline \multirow{2}{*}{$\begin{array}{c}\text { Ground } \\
\text { Fertilization }\end{array}$} & \multicolumn{4}{|c|}{ Foliar Spraying with Seaweed Extract } & \multirow{2}{*}{ Average } \\
\hline & A0 & A1 & A2 & A3 & \\
\hline F0 & 1.09 & 1.26 & 1.29 & 1.31 & 1.24 \\
\hline F1 & 1.33 & 1.35 & 1.36 & 1.39 & 1.36 \\
\hline F2 & 1.42 & 1.43 & 1.45 & 1.47 & 1.44 \\
\hline F3 & 1.48 & 1.52 & 1.56 & 1.59 & 1.54 \\
\hline average & 1.33 & 1.39 & 1.42 & 1.44 & \\
\hline L.S.D0.05 & \multicolumn{2}{|c|}{$\mathrm{F}=0.186$} & \multicolumn{2}{|c|}{$\mathrm{A}=0.186$} & $\mathrm{~F}^{*} \mathrm{~A}=0.382$ \\
\hline
\end{tabular}

\subsection{Boron Content of Leaves (mg.kg-1)}

Table 6 showed significant differences between the average boron content of leaves for apricot trees, cultivar Zaini under study because of adding high-potassium fertilizer. The trees differed significantly and excelled among trees treated with Qrop Complex at a concentration of 600 g.tree- 1 and Which gave the highest average of boron content of leaves (48.04 mg.kg-1) while the control treatment gave $(30.88 \mathrm{mg} . \mathrm{kg}-1)$. The trees under research varied among themselves in their effect on the boron content of leaves when sprayed with seaweed extract, as shown in the same table. The trees treated with $3 \mathrm{ml} . \mathrm{L}-1$ Alge-Zone performed best and produced the greatest average of (41.82 mg.kg-1). The trees that had not been treated had the lowest average for this attribute, which was (37.48 mg.kg-1). As shown in the same table, the interaction between the fertiliser treatment Qrop Complex and Alge-Zone seaweed extract had a substantial impact on the boron content of the leaves. The trees treated with Qrop Complex fertiliser at a dosage of 600 g.tree-1 and foliar spraying with seaweed extract Alge-Zone at a concentration of $3 \mathrm{ml} . \mathrm{L}-1 \mathrm{had}$ the greatest average boron content in leaves $(50.30 \mathrm{mg} . \mathrm{kg}-1)$ When the control treatment was used, the leaves had the lowest average boron level (28.61 mg.kg-1).

Table 6. Boron concentration of leaves (mg.kg-1) for apricot trees cultivar Zaini after ground fertilisation and foliar spraying with seaweed extract.

\begin{tabular}{|c|c|c|c|c|c|}
\hline \multirow{2}{*}{$\begin{array}{c}\text { Ground } \\
\text { Fertilization }\end{array}$} & \multicolumn{4}{|c|}{ Foliar Spraying with Seaweed Extract } & \multirow{2}{*}{ Average } \\
\cline { 2 - 5 } & $\mathrm{A} 0$ & $\mathrm{~A} 1$ & $\mathrm{~A} 2$ & $\mathrm{~A} 3$ & \\
\hline
\end{tabular}




\begin{tabular}{|c|c|c|c|c|c|}
\hline F0 & 28.61 & 29.18 & 31.96 & 33.75 & 30.88 \\
\hline F1 & 34.72 & 35.11 & 36.96 & 38.45 & 36.31 \\
\hline F2 & 39.73 & 42.73 & 43.53 & 44.77 & 42.69 \\
\hline F3 & 46.86 & 47.20 & 47.80 & 50.30 & 48.04 \\
\hline average & 37.48 & 38.56 & 40.06 & 41.82 & \\
\hline L.S.D0.05 & \multicolumn{2}{|c|}{$\mathrm{F}=9.838$} & $\mathrm{~A}=9.838$ & $\mathrm{~F}^{*} \mathrm{~A}=$ \\
& \multicolumn{3}{|c}{} & & 19.676 \\
\hline
\end{tabular}

\subsection{Iron Content of Leaves (Mg.Kg-1)}

Because of the ground addition of the fertiliser Qrop Complex, significant variations in the average iron content of leaves are shown in Table 7. At a concentration of 600 g.tree-1, the fertiliser considerably improved the trees. As indicated in Table 7, apricot trees differed in their average iron content of leaves when sprayed with seaweed extract, with the highest average for this feature (231.18 mg.kg-1), and the lowest average for the same trait (control treatment without spraying) (216.34 mg.kg-1). The interaction of Qrop Complex and seaweed extract in the leaves had a clear influence on the iron content of the leaves. Trees were given a $600 \mathrm{~g}$ fertiliser treatment, with tree- 1 interfering with a $3 \mathrm{ml}$ concentration of seaweed extract. When compared to the control treatment, which delivered the lowest average for the same attribute (251.67 mg.kg-1), L-1 excelled and gave (251.67 mg.kg-1) (185.00 mg. kg-1).

Table 7. Effect of ground fertilization and foliar spraying with seaweed extract on Iron content in the leaves (mg.kg-1) for apricot trees cultivar Zaini.

\begin{tabular}{|c|c|c|c|c|c|}
\hline \multirow{2}{*}{$\begin{array}{c}\text { Ground } \\
\text { Fertilization }\end{array}$} & \multicolumn{4}{|c|}{ Foliar Spraying with Seaweed Extract } & \multirow{2}{*}{ Average } \\
\cline { 2 - 5 } & A0 & A1 & A2 & A3 & \\
\hline F0 & 185.00 & 190.00 & 199.00 & 208.33 & 195.58 \\
\hline F1 & 211.67 & 217.67 & 222.00 & 226.00 & 219.34 \\
\hline F2 & 227.67 & 231.67 & 234.00 & 238.67 & 233.00 \\
\hline F3 & 241.00 & 246.67 & 248.67 & 251.67 & 247.00 \\
\hline average & 216.34 & 221.50 & 225.92 & 231.18 & \\
\hline L.S.D0.05 & \multicolumn{3}{|c|}{ F= 2.674 } & A $=2.674$ & \multirow{2}{*}{$F^{*} \mathrm{~A}=5.349$} \\
\hline
\end{tabular}

\subsection{Fruit Weight (g)}

Table 8 shows that a high potassium fertiliser, Qrop Complex, was used at an average rate of 600 g.tree-1. It had a substantial influence on the fruit weight of apricot trees of cultivar Zaini, where these plants excelled and gave the greatest average of that feature of $(16.14 \mathrm{~g})$ when compared to the control treatment, which offered the lowest average of that attribute $(11.97 \mathrm{~g})$. The table also shows that the weight of the fruit varies between the trees. The trees sprayed with 
Alge-Zone seaweed extract at a concentration of 3 ml.L-1 outperformed the other concentrations, averaging $14.66 \mathrm{~g}$, compared to the control treatment, which had the lowest average for the same attribute. (13.48 g) \&nbsp;\&nbsp;\&nbsp The significance of the apricot trees with the soil fertiliser at an average of $600 \mathrm{~g}$ is indicated by the results of the interaction between the treatment of the Qrop Complex fertiliser with the seaweed extract Alge-Zone, as shown in the table. The interaction of Tree- 1 with seaweed extract at a concentration of 3 ml.L1 produced the highest average for the same characteristic. $(16.69 \mathrm{~g})$ in comparison to the control therapy, which produced the lowest average for this feature of $(11.18 \mathrm{~g})$.

Table 8. Effect of ground fertilization and foliar spraying with seaweed extract on Fruit weight $(\mathrm{g})$ for apricot trees cultivar Zaini.

\begin{tabular}{|c|c|c|c|c|c|}
\hline \multirow{2}{*}{$\begin{array}{c}\text { Ground } \\
\text { Fertilization }\end{array}$} & \multicolumn{4}{|c|}{ Foliar Spraying with Seaweed Extract } & \multirow{2}{*}{ Average } \\
\cline { 2 - 5 } & $\mathrm{A} 0$ & $\mathrm{~A} 1$ & $\mathrm{~A} 2$ & $\mathrm{~A} 3$ & \\
\hline F0 & 11.18 & 12.02 & 12.15 & 12.51 & 11.97 \\
\hline F1 & 12.94 & 13.04 & 13.68 & 13.88 & 13.39 \\
\hline F2 & 14.20 & 14.74 & 15.01 & 15.30 & 14.81 \\
\hline F3 & 15.61 & 15.93 & 16.06 & 16.96 & 16.14 \\
\hline average & 13.48 & 13.93 & 14.23 & 14.66 & \\
\hline L.S.D0.05 & \multicolumn{2}{|c|}{$\mathrm{F}=1.771$} & $\mathrm{~A}=1.771$ & $\mathrm{~F} * \mathrm{~A}=3.543$ \\
\hline
\end{tabular}

\subsection{The Yield of One Tree $\left(\mathrm{Kg}^{-1}\right)$}

Because of the use of this fertiliser, Table 9 demonstrated changes in the yield average of one tree for apricot trees, cultivar Zaini under research. The trees differed, with the trees fed with Qrop Complex fertiliser at a concentration of $600 \mathrm{~g}$ excelling. The tree with the highest average yield per tree was Tree-1 (15.05 tree .kg-1). The control therapy, on the other hand, produced the lowest average for the same feature, which was (11.78 tree .kg-1). The trees under research differ in their effect on the yield of one tree when sprayed with seaweed extract, as shown in the same table. The trees treated with $3 \mathrm{ml} . \mathrm{L}-1$ Alge-Zone performed best and produced the greatest average of (13.95 tree .kg-1). While the untreated trees had the lowest average for that attribute (12.88 tree.kg-1), the interaction between the Qrop Complex ground fertiliser and the seaweed extract Alge-Zone altered the output of one tree. As shown in the same table, trees treated with Qrop Complex fertiliser at a concentration of 600 g.tree-1 in combination with foliar spraying with seaweed extract Alge-Zone at a concentration of $3 \mathrm{ml} . \mathrm{L}-1$ yielded the highest average of yield per tree (15.77 tree.kg-1), while the control treatment yielded the lowest average for this trait (15.77 tree.kg-1) (10.65 tree .kg-1).

Table 9. Effect of ground fertilization and foliar spraying with seaweed extract on the Tree yield $\left(\mathrm{kg}^{-1}\right)$ for apricot trees cultivar Zaini.

\begin{tabular}{|c|c|c|c|c|c|}
\hline \multirow{2}{*}{$\begin{array}{c}\text { Ground } \\
\text { Fertilization }\end{array}$} & \multicolumn{4}{|c|}{ Foliar Spraying with Seaweed Extract } & \multirow{2}{*}{ Average } \\
\cline { 2 - 5 } & $\mathrm{A} 0$ & $\mathrm{~A} 1$ & $\mathrm{~A} 2$ & $\mathrm{~A} 3$ & \\
\hline F0 & 10.65 & 11.84 & 12.10 & 12.51 & 11.78 \\
\hline F1 & 12.77 & 12.87 & 13.02 & 13.23 & 12.97 \\
\hline
\end{tabular}




\begin{tabular}{|c|c|c|c|c|c|}
\hline F2 & 13.50 & 13.74 & 14.01 & 14.30 & 13.89 \\
\hline F3 & 14.59 & 14.84 & 15.01 & 15.77 & 15.05 \\
\hline average & 12.88 & 13.32 & 13.54 & 13.95 & \\
\hline L.S.D0.05 & \multicolumn{2}{|c|}{$\mathrm{F}=1.902$} & $\mathrm{~A}=1.902$ & $\mathrm{~F}^{*} \mathrm{~A}=3.804$ \\
\hline
\end{tabular}

\subsection{Percentage of Total Soluble Solids (T.S.S)}

The percentage of total soluble solids (TSS) for the apricot trees understudy was significantly affected by fertilising with Qrop Complex fertiliser at an average rate of 600 g.tree-1, as shown in Table 10. These trees outperformed the control treatment, yielding the greatest average for that attribute (15.29 percent) compared to the control treatment, which yielded the lowest average (13.41 percent ). The proportion of total soluble solids (TSS) differs among the trees in the same table, with the trees sprayed with seaweed extract Alge-Zone at a concentration of 3 $\mathrm{ml}$ having the highest TSS. L-1 surpassed the other concentrations, yielding (14.69 percent) compared to 14.13 percent for the control. The relevance of the trees that were fertilised with the fertiliser Qrop Complex at an average of $600 \mathrm{gm}$ is indicated by the findings of the same table for the interaction between the treatment of the Qrop Complex fertiliser with the seaweed extract Alge-Zone. When compared to the control treatment, which had the lowest average for this feature (15.66 percent), the highest average in percentage of total soluble solids (TSS) was (15.66 percent) (13.04 percent).

Table 10. Effect of ground fertilization and foliar spraying with seaweed extract on the percentage of total soluble solids (T.S.S) for apricot trees cultivar Zaini.

\begin{tabular}{|c|c|c|c|c|c|}
\hline \multirow{2}{*}{ Ground Fertilization } & \multicolumn{4}{|c|}{ Foliar Spraying with Seaweed Extract } & \multirow{2}{*}{ Average } \\
\hline & A0 & A1 & A2 & A3 & \\
\hline F0 & 13.04 & 13.29 & 13.57 & 13.74 & 13.41 \\
\hline F1 & 13.90 & 14.07 & 14.25 & 14.38 & 14.15 \\
\hline F2 & 14.57 & 14.63 & 14.72 & 14.96 & 14.72 \\
\hline F3 & 15.04 & 15.17 & 15.27 & 15.66 & 15.29 \\
\hline average & 14.13 & 14.29 & 14.45 & 14.69 & \\
\hline L.S.D0.05 & \multicolumn{2}{|c|}{$\mathrm{F}=1.428$} & \multicolumn{2}{|c|}{$\mathrm{A}=1.428$} & $\mathrm{~F}^{*} \mathrm{~A}=2.857$ \\
\hline
\end{tabular}

\section{Discussion}

\subsection{Effect of Ground Fertilization on The Leaves Content of Chlorophyll and Mineral Elements (N, P, K, B, Fe)}

Tables from 2-7 show the significance of trees fertilized with this fertilizer on the control treatment (without adding). The reason for the increase in this trait maybe since this fertilizer contains nutrients necessary for growth, especially potassium, which works to stimulate enzymes related to physiological processes such as photosynthesis. It also helps in the movement and transfer of food manufactured in the leaves to other plant tissues, which increased 
the manufacture of food manufactured in the leaves as a result of containing good quantities of major elements, which increased the content of the leaves of chlorophyll and mineral elements, as the increase of these elements in the plant as a result of processing and absorption from before the plant, Fertilizing of fruit trees with compounds containing one or more nutrients necessary for plants to improves their nutritional status as well as their growth, nitrogen is the main component in mineral fertilizers that are added to plants, it encourages vegetative and root growth of plants and strengthens the root group, It's a necessary part of cell protoplasm. It accounts for 2-4 percent of the plant's dry matter after water. It's found in a wide range of chemical molecules, including amino acids, proteins, nucleic acids, enzymes, and plant hormones. It also forms an essential part of the dye for photosynthesis (chlorophyll) and gives the plant a green colour, While phosphorous is necessary for several vital processes such as photosynthesis, carbohydrates, energy transfer within the plant and cell division, it enters the composition of nucleic acids, energy-carrying compounds, and some enzymes, accelerates the early formation of roots and increases their growth and spread in the soil, as well as accelerating the flowering of trees and comes in second place After nitrogen in terms of the quantities needed by the plant, and potassium is necessary for several physiological processes within the plant such as building sugars, starch, proteins and cell division [20].

\subsection{The Effect of Ground Fertilization on The Weight of The Fruit, The Yield of One Tree, and The Percentage of Total Soluble Solids}

The data in Tables 8-10 show that this is the case, and the explanation for this could be related to improved tree vegetative growth. As a result of the growth in processed foodstuffs that develop leaves and collect them in the fruits, the number of fruits left on the tree at harvest increased. As a result of digesting nutrients and boosting their absorption from the soil, this had a favourable impact on tree yields, resulting in a rise in the trees' benefit from them in terms of improving their vegetative and fruit growth [20].

\subsection{Effect of Seaweed Extract on Chlorophyll Content and Mineral Elements (N, P, K, B, Fe) In Leaves.}

Tables 2-7 show that foliar spraying with seaweed extract had a clear effect on the attributes studied. These compounds increase the growth of the vegetative system, increase the quantity of yield, improve its quality, delay the aging of fruits, and increase plant resistance to biotic and abiotic stress. [21]. These extracts also have a great role as primary products of organic materials, and synthetic materials such as seaweed extract cells consist of many important compounds such as sugars, amino acids, RNA, DNA, and enzymes, as well as proteins [22]. Vitamins and minerals are significant molecules because of their involvement in boosting the efficiency of the photosynthetic process, increasing the produced materials in the leaves, and increasing the mineral content of the leaves [23].

\subsection{Effect of seaweed extract on fruit weight, yield per tree, and percentage of total soluble solids:}

It is evident from the results presented in Tables 8-10 to the increase that occurred when spraying with seaweed extract. The reason for this may be due to the improvement of the vegetative growth of trees and thus the increase in processed foodstuffs that grow leaves and combine them with young fruits in an increase in yield. Which led to an increase in the number 
of fruits remaining on the tree when harvesting, which was positively reflected on the yield of trees because of processing nutrients and increasing their absorption from the soil, which led to an increase in the trees' benefit from them in improving their vegetative and fruit growth. When trees are treated with seaweed extracts, the quality of orange fruits improves as the percentage of sugars in them increases [24]. Also, these extracts increase the efficiency of nutrient absorption, increase the processes of photosynthesis and respiration, and these compounds may act as an antioxidant because they contain alpha-tocopherol, beta-carotene, niacin, thymine, and ascorbic acid, and through their role in increasing the activity of many enzymes [22]. As for the treatment of the interaction between the Qrop Complex fertilizer and the seaweed extract, its effect was clear in giving the best results. The reason may be due to the result of their interaction, thus giving a clear surge in the studied characteristics.

\section{References}

[1] Taha Sheikh Hassan. 2002 . Encyclopedia of almond fruit. first edition. Aladdin House Publications. Syria. p. 352.

[2] Punia, M.S .2007. Wild Apricot. National Oil Seeds and Vegetable Oils Development Board. Ministry of Agriculture, Govt. of India

[3] Al-Douri, Ali and Adel Al-Rawi. 2000. Fruit production. first edition. Book publishing house. University of Al Mosul. p. 528.

[4] Janick, J . 2005 .The origin of fruits, Fruit growing and Fruit breeding. Plant Breeding. Rev.25: 255320.

[5] Bal, J. S .2005 . Fruit Growing. 3th edt. Kalyani Publishers, New Delhi. India.

[6] Prasad, R. and Power, J.F. 1997. Soil Fertility Management for Sustainable Agriculture. Lewis Publishers in an Imprint of CRC Press, 243.

[7] Jassim M. A. Al-Aa'reji and Jihad Sh. K. Perot .2017. Effect of some liquid organic and (NPK) fertilizers on growth and fruiting of apricot trees "Prunus armeniaca L. "cv. Royal . Collage of Agriculture and Forestry/ University of Mosul

[8] HUSSEIN,M.M. ,M.M.SHAABAN AND A.K.M.EL-SAALY . 2008 . Response of cowpea plant grown under salinity stress to n p,k-foliar application .American J.of plant physiology 3 (2),2008, 81-88.

[9] Al-Sahaf, Fadel Hussein. (1989). Applied plant nutrition. University of Baghdad - Ministry of Higher Education and Scientific Research.

[10] TISDALE, S.L., NELSON, J. AND D. BEATON. 1993 . Soil Fertility and Fertilizer. Prentice Saddle River. New Jersey. USA.1993, P. 220.

[11] O'Dell, C. 2003. Natural Plant Hormones are Biostimulants Helping Plants Develop High Plant Antioxidant Activity for Multiple Benefits. Virginia Vegetable, Small Fruit and Specialty Crops. 2 (6): $1-3$

[12] Demir,N.;B.Dural\&K.Yildirim.2006.Effec to of seaweed suspensions on seed germination of tomato,pepper and aubergine. J.Biol.Sci.6:1130-1133.

[13] Ayad,J.Y.1998.TheEffect of SeaweedAscophyllumnodosumExtract on Antioxidant Activities and Drought Tolerance of Tall Fescue FestucaarundinaceaSchreb .Ph.D.thesis. agronomy department. Texas Tech.University.Pp.158.

[14] Felix Loh, j. G. and B. Nina. 2000. Use of the Minolta SPAD- 502 to determine chlorophyll concentration in ficus benjamina L. and populus deltoid's Marsh leaf tissue . Hort. Science. 35 (3) :p.423.

[15] Black, C.A. 1965.Methods of Soil Analysis.Part 2.Amer.Soc.of Agron.Inc.U.S.A.

[16] Olsen, S.R.;C.V.Coil;F.S.Watanabe, and L.A.Dean. 1954. Estimation of available phosphorus in soil by extraction with sodium bicarbonate. USDA-Circular, 939:1-9. 
[17] Richards, L.A. 1954 .Diagnosis and Improvement of Saline and Alkali Soils.U.S.D.A.Handbooks No.60.

[18] Chapman , H. D and F.P pratt. 1961. Methods of analysis for soils, plants and water . univ. of calif. Div. Davision of Agric. Sci. p.309.

[19] Al-Nuaimi, Saadallah Najm. 1999 . Fertilizers and soil fertility. Ministry of Higher Education and Scientific Research, University of Mosul. House of books for printing and publishing.

[20] Nijjar, G. S. 1985. Nutrition of Fruit Trees. Published by Mrs Usha Rajumar for Kalyani, India, New Delhi, pp: 10-52.

[21] Demir,N.;B.Dural\&K.Yildirim.2006.Effec to of seaweed suspensions on seed germination of tomato,pepper and aubergine. J.Biol.Sci.6:1130-1133..

[22] Doug ,S; L..Change ;C.F.scagel and L.H.Fuchigami .2005 .Timing of urea applactioneffects leaf and root $\mathrm{N}$ uptake in young fugi / M.9 apple trees.

[23] Al-Mayah, Abdel Reda Amwan and Ibrahim Hameem Flyer. 1991. Aquatic plants and algae. The first part. Ministry of Higher Education and Scientific Research. Albasrah university

[24] Fornes,F.;M.Sanchez\& J.L.Guardiola.2002 Effect of a seaweed extract on the productivity of"deNules"Clementine Mandarin and Navelinaorange.Botanica Marina.45(5):487-489. 